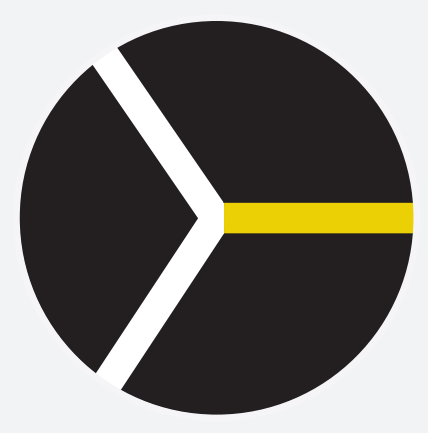

TECHNOLOGY GOVERNANCE

Working Papers in Technology Governance and Economic Dynamics no. 35

THE OTHER CANON FOUNDATION, NORWAY

TALLINN UNIVERSITY OF TECHNOLOGY, TALLINN

CONTACT: Rainer Kattel, kattel@staff.ttu.ee; Wolfgang Drechsler, drechsler@staff.ttu.ee; Erik S. Reinert, reinert@staff.ttu.ee

\title{
Where do Innovations Come From? Transformations in the U.S. Economy, 1970-2006
}

Fred Block, Department of Sociology, University of California, Davis

Matthew R. Keller, Department of Sociology, Southern Methodist University

May 2011

Forthcoming in Knowledge Governance: Reasserting the Public Interest, edited by Leonardo Burlamaqui, Ana Celia Castro and Rainer Kattel, Anthem Press, 2011.

* This paper was supported with funding from the Ford Foundation. An early version of this paper was published as a working paper by the Information Technology and Innovation Foundation in Washington, D.C. Another version was published in Socio-Economic Review and reprinted as a chapter in Fred Block and Matthew R. Keller, editors, State of Innovation: The U.S. Government's Role in Technology Development. Jason Logan, John Kincaid, and Chris Knight provided valuable research assistance, and we are grateful for comments received in several different settings where we presented the findings, including the Power and Inequality Workshop at U.C. Davis and the American Sociological Association meetings, August 2008. 


\begin{abstract}
This article brings to bear new data on the issue of structuring national innovation systems. Drawing on a unique data set of prize winning innovations between 1971 and 2006, we document three key changes in the U.S. economy. The first is an expanding role of interorganizational collaborations in producing award winning innovations. The second is the diminishing role of the largest corporations as sources of innovation. The third is the expanded role of public institutions and public funding in the innovation process. This leads us to the surprising conclusion that the U.S. increasingly resembles a Developmental Network State in which government initiatives are critical in overcoming network failures and in providing critical funding for the innovation process. The paper concludes by addressing the implications of these finding for debates over the appropriate regime for intellectual property rights.
\end{abstract}

\title{
1. Introduction
}

There is growing international recognition that nations that develop more effective national systems of innovation will have a significant advantage in the global economy. And that recognition, in turn, has led to intense debates over which rules for governing intellectual property are most consistent with a strong innovation system. The problem, however, is that most of the empirical work on this question has focused on the analysis of data on patenting rates across countries and by different types of firms. But patent rates are a problematic proxy for effective innovation, and there is a danger that reliance on this proxy is producing a distorted understanding of the circumstances under which innovation occurs and the intellectual property regimes that might best facilitate such innovation.

This paper brings a quite different data source to bear on understanding changes in the U.S. innovation system over the last four decades. The data set is a sample of key innovations in the U.S. economy drawn from an annual awards competition for innovative products organized by $R \& D$ Magazine between 1971 and 2006. By looking not at patent data but at actual new products that are admired by prize juries, we hope to illuminate the changing sources of innovation in the U.S. economy. ${ }^{1}$

\section{Reviewing the Literature}

In The Coming of Post-Industrial Society, the late sociologist Daniel Bell provided the most systematic elaboration of the postindustrial concept. In his analysis, postindustrial change is driven by the systematic harnessing by

\footnotetext{
1 For another analysis of this data source, see Roberto Fontana, Alessandro Nuvolari, Hiroshi Shimitzu, and Andrea Vezzulli, "Schumpeterian Patterns of Innovation and the Sources of Breakthrough Inventions: Evidence from a Data-Set of R\&D Awards," unpublished paper, October 2010.
} 
both business and government of science and technology to expand and continuously update the production of goods and services. For Bell, the rise of the computer industry in the fifties and sixties with its armies of skilled technologists was a paradigmatic case of this broader process of transformation. Bell anticipated that the growing dependence of business on scientists, engineers, and technicians would necessitate larger shifts in business organization and in the role of government.

Bell also anticipated that scientists and engineers would transform both products and processes across the full range of industries in much the same way that industrial technologies diffused across all sectors of the economy over the Nineteenth Century. Craft knowledge and traditional production techniques would give way to sophisticated science-based approaches that enhanced efficiency and created a cornucopia of new goods and services. "This new fusion of science with innovation, and the possibility of systematic and organized technological growth, is one of the underpinnings of the post-industrial society" (Bell 1973, p. 197).

Bell's foresaw significant changes in the corporation as scientists, engineers and other members of a "new intelligentsia" rose in importance.

"If the dominant figures of the past hundred years have been the entrepreneur, the businessman, and the industrial executive, the 'new men' are the scientists, the mathematicians, the economists, and the engineers of the new intellectual technology." (344)

The argument pointed both to the growing role that technical experts would play in top management positions and to structural changes in the organization of firms. While Bell did not address the issue explicitly, his argument paralleled those of Burns and Stalker (1961) and Bennis and Slater (1968), who argued that the growing centrality of technological expertise would push organizations to be both less authoritarian and less hierarchical, moving from steeper to flatter organizations with greater emphasis on coordination by multi-disciplinary teams.

Bell was even bolder in arguing that postindustrial change would transform the relationship between business and government. On the one side, government's dominant role in financing scientific and technological research greatly enhanced its role in the economy. On the other, Bell argued that corporations would have to move beyond narrow profit-maximizing strategies if they were to take full advantage of the new technological possibilities. Hence, he foresaw a new balance of power between business and government:

"It seems clear to me that, today, we in America are moving away from a society based on a private-enterprise market system toward one in which the most important economic decisions will 
be made at the political level, in terms of consciously defined 'goals' and 'priorities'." (Bell 1973, pp. 297-298)

Although Bell's framework is now infrequently referenced (see, however, Block 1990, Brick 2006)), several currents of research have followed up on these arguments. A growing body of scholarly work over the last two decades focuses on "national systems of innovation" to track how different societies organize the complex task of linking scientific research with product and process innovations (Collins 2004; Lundvall 1992; Nelson 1993). This literature rests on the idea that innovation capacity is centrally important as nations seek to gain advantage in the world economy.

Many of these studies of innovation systems focus on the interface between the public and private sector, looking particularly at public funding of research and higher education, the growth of the scientific and technical labor force, the systems for establishing and protecting intellectual property rights for innovators, and the mechanisms that facilitate the movement of ideas from the research lab to the market. The great strength of this literature is that it looks simultaneously at the role of government and the role of business and raises important questions about the interaction between the two. Nevertheless, this work has identified an important focus of inquiry, but it has not yet identified systematic and causally significant variations in the organization of innovation systems across nations.

A second relevant body of work consists of studies that analyze the shift of business firms, particularly in the United States, towards networked forms of organization. This shift represents a reversal of a pattern of corporate development that started in the last years of the $19^{\text {th }}$ century. Back then, successful U.S. firms aspired to a high level of vertical integration which meant controlling many different stages of the production process under one corporate roof (Fligstein 1990). Some of these firms attained high levels of self-sufficiency, often financing their growth with retained profits and drawing much of their technology from their own research laboratories. However, with gathering speed over the last half century, there has been a significant shift in the dominant business model away from vertical integration (Castells 1996; Powell 2001).

Many firms have shifted key parts of the production process to supplier firms. The trend is exemplified both by Nike, which has outsourced the production of its athletic shoes, and the increased reliance of Detroit automakers on subcontractors to produce many key parts of their automobiles (Whitford 2005). But the pattern also extends to the research and development function where many firms are less reliant on their own laboratories and more involved in complex webs of collaboration with other firms, universities, and government laboratories (Hounshell 1996; Mowery 2009; Powell 2001). 
Implicit in much of the literature on networked firms is the idea that there will be much more fluidity than in a world of vertically integrated firms. New firms will continue to form as a result of spinoffs from existing firms and from university and government laboratories. Moreover, some of these newcomers will be able to exploit their initial role as subcontractors to establish superiority in important new technologies in the way that Microsoft gained strategic control over the operating system for IBM's personal computers. Similarly, large established firms are at risk of precipitous decline if they fail to remain at the frontier of innovation. This gives us our first research question: over the last four decades, has there been a decline in the role of the largest firms as developers of innovative new technologies, or have the largest firms continued to serve as the central nodes of innovation networks?

The rise of a networked industrial structure is particularly obvious in the computer industry and in biotechnology (Powell, White, Koput and Owen-Smith 2005; Saxenian 1994). In both industries, small and large firms are involved in elaborate collaborative networks, and it is widely recognized that innovation grows out of processes of cooperation that cross organizational lines. But research to date has been unclear as to whether this pattern of inter-organizational collaboration is characteristic of the entire economy or confined to the most technologically dynamic sectors. Our second research question is whether or not the shift towards inter-organizational collaboration in the innovation process has been a general trend across the entire economy.

A final body of literature has documented the emergence of a triple helix of intertwined efforts by government, universities, and corporations to produce more rapid innovation. Extending Bell's analysis, this body of work shows how tightly university-based science efforts are now linked to industry, but it also shows that government agencies are playing an increasingly central role in managing and facilitating the process of technological development (Block 2008; Etzkowitz 2003; Geiger and Sa 2008; Kenney 1986). In cases such as the Human Genome Project, organized by NIH and the Department of Energy, and the Strategic Computing Initiative organized by DARPA, government officials have played a central role in both setting technological goals and providing the funding to facilitate joint efforts by university-based researchers and business (Kevles 1992; McCray 2009; Roland 2002).

These targeted government programs have been combined with a highly decentralized system for encouraging innovation. Starting in the 1980's, new incentives were created for publicly funded researchers at universities and government laboratories to pursue commercial applications of their discoveries. Such efforts have been supported by funding programs, such as the Small Business Innovation Research (SBIR) program through which government agencies set aside a small percentage of their R\&D budgets for projects pro- 
posed by small firms, many of which are newly created spinoffs from university or federal laboratories (Wessner 2008). Other programs have been created to encourage joint ventures between researchers in university and federal laboratories and business firms (Block 2008; Geiger and Sa 2008). This provides us with our third research question: has there been a marked increase in the public sector's role in funding and facilitating innovation efforts?

Exploring each of these questions requires finding some way to measure innovative activities. However, the measurement of innovation has been a longstanding problem for social scientists. It is not adequate to count the dollars spent on research and development or the number of scientists and technologists at work since these are simply inputs to the innovation process. Many studies have used patent statistics as a proxy, but these are a problematic indicator because the rate of successful patenting does not necessarily track changes in useful innovations.

The quality of patents can vary significantly over time as a consequence of shifts in policy that govern patent offices and changes in the incentives of different economic actors (Sciberras 1986, Taylor 2004). For example, one study showed that many universities in the U.S. significantly increased the quantity of their patent filings in the aftermath of the Bayh-Dole legislation. However, the quality of the resulting patents, as reflected in subsequent citations, also fell substantially (Mowery, Nelson, Sampat, and Ziedonis 2001; Thursby and Thursby 2002). Similarly, there has been an increase in "strategic patenting" by corporations and other actors in recent years.

Strategic patenting refers to the acquisition of a patent without any serious interest in developing products that use the patent. An individual or firm that acquires a portfolio of such strategic patents can sometimes make a significant return by suing other firms for infringement of those patents. There is some debate about the size of the problem posed by these "patent trolls", but the phenomenon has received a lot of attention. Probably the more serious problem is that large corporations have been aggressive in acquiring substantial portfolios of strategic patents as a defensive maneuver. If they are sued by another firm for infringing an existing patent, they might use some of the patents in their portfolio to mount a countersuit against the other firm. If the suits have somewhat similar levels of plausibility, the chances of negotiating a settlement increase significantly.

In short, an increase over time in the amount of strategic patenting could easily alter the relationship between patents and actual usable new products or processes. For this reason, we use a data set of award winning innovations to illuminate structural shifts in the U.S. economy that have occurred over the last four decades. This data set shows much more substantial changes over time than those revealed in patenting data. 


\section{Introducing the Data}

For more than forty years, $R \& D$ Magazine has annually recognized 100 innovations that are incorporated into actual commercial products. These awards are comparable to the Oscars for the motion picture industry; they carry considerable prestige within the community of research and development professionals. Organizations nominate their own innovations and a changing jury that includes representatives from business, government, and universities, in collaboration with the magazine's editors, decide upon the final list of awards (the nomination and selection procedures are described on the magazine's website at http://www.rdmag.com/100win.html). The awards go to commercial products that were introduced into the marketplace during the previous year. The entry forms require evidence of the availability of the product and its price. With 100 innovations that can be recognized, juries are able to recognize the full diversity of innovative products, not just to focus on dynamic sectors such as electronics or biotechnology.

We coded all of the winning innovations for three randomly chosen years in each of the last four decades to identify the types of organizations that were responsible for nurturing the award winners. [Full data is provided in Appendix 1] Since 1971, somewhere between five and thirteen of the awards each year went to foreign firms that had no U.S. partners. ${ }^{2} \mathrm{We}$ excluded those cases and focused our analysis on the roughly ninety award winners each year that involved U.S.-based firms.

While the awards recognize innovations in a wide range of different industries, there are some biases in the process. The awards are tilted towards product innovations rather than process innovations-those that are designed to raise the efficiency of the production process for goods and services. Some process innovations, such as a new type of machine tool or a more advanced computer program for managing inventories, are recognized, but many important process innovations are not considered because they involve complex combinations of new equipment and new organizational practices. Many military innovations are also excluded, since cutting edge weapons are usually shrouded in secrecy and unavailable for purchase. Since the great bulk of federal R\&D dollars are still directed towards weapons systems, many government funded innovations lie outside of this competition.

Furthermore, the awards are structured to recognize just the tip of the proverbial iceberg - the last steps in the innovation process. The many ear-

\footnotetext{
2 The only exceptions occur when a foreign firm owns a large, established U.S. business, such as when Chrysler was owned by Daimler Benz. In such cases, we code the firm as a Fortune 500 firm.
} 
lier steps are submerged and out of sight. This bias means that the awards understate the role of university-based research since detailed case studies suggest that many key innovations can be traced back to scientific breakthroughs in university laboratories (Roessner et. al. 1997).

What other biases might enter the awards process? Questionable decisions and politics will always be a factor as jury members seek to reward friends and deny recognition to enemies. But for our purposes, it is not necessary that these awards recognize the very best innovations of any particular year. All that is necessary is that the awardees represent a reasonable cross section of innovative products and that there is not a consistent bias that favors awardees of a particular type.

Different resources that organizations have to prepare their nomination materials are another potential source of bias in competitions. Big architectural firms, for example, can hire the best photographers and devote considerable resources to a nomination while the hard-pressed solo practitioner might throw the application form together in a few hours (Larson 1993, 1994). There is probably a similar bias in these awards with larger organizations having more expertise at putting together persuasive nomination packets.

However, there are reasons to think that the magnitude of this bias would be limited. For one thing, the universe of applicants is limited to organizations that have actually developed a commercial product, and since winning the award is a powerful form of advertising, even the tiniest firms have strong incentives to devote resources to an effective application. For another, the quality of "coolness" that engineers and technologists admire in a product is substantially easier to convey in words than the more abstract, aesthetic qualities that architectural or film juries might be rewarding. Finally, over the years there are many one-time winners, which reinforces the impression that it is the quality of the product and not the quality of the nomination packet that wins awards.

There are, however, two distinct biases in the awards that are important for interpreting our results. First, it is very rare for the $R \& D 100$ awards to recognize new pharmaceutical products. While there are many awards for medical devices and equipment, there seems to be a deliberate decision to avoid medications of all kinds. Our assumption is that this reflects an abundance of caution by the magazine, which does not want the bad publicity or legal liability of recognizing a product that might later be found to have negative side effects.

A second exclusion is more surprising. There are few awards over the last twenty years for products-either hardware or software-developed by the 
largest computer firms. Apple did not win an award for the iPod, Microsoft has received only one R\&D award since it began, and firms such as Intel, Sun Microsystems, and Cisco have each won only once. Many of the products of this industry represent incremental improvements such as new versions of software packages or slightly improved notebook computers and it is logical that the jurors ignore these. But it also seems likely that even when they produce a more dramatic innovation, jurors hold them to higher standards than those used for other organizations.

While these two exclusions indicate the need for caution in interpreting the results, they are analytically fortuitous. Since the data largely leave out big firms in the two industries - biotechnology and computing - that are generally seen as paradigmatic examples of science-based production, strong network ties among firms, and substantial governmental involvement in the innovation process, the awards data allows us to take a broader view of the innovation economy. To what degree are the same trends effecting sectors that have not been as strongly associated with science-based production?

\subsection{Coding}

It would be ideal to code both the organizational auspices and the funding sources for every innovation awarded in the twelve competitions that we analyze. But while the organizational auspices can be established with a reasonable amount of research, uncovering the funding sources for almost 1200 different innovations is an almost impossible task. The primary difficulty is that tracking flows of federal support to businesses is laborious and complicated. In our data, we coded the organizational auspices as completely as possible for the roughly 1200 innovations. Our approach to establishing the funding sources of the recognized innovations represents a compromise. We performed a detailed analysis of federal funding to award-winning firms and innovations for the years 1975 and 2006 to maximize the contrast across time.

In organizational terms, the data revealed seven distinct loci from which the award-winning innovations originated. They are:

\section{Private}

1. Fortune 500 firms operating alone.

2. Other firms operating on their own; this is a residual category that includes small and medium sized firms.

3. Collaborations among two or more private firms with no listed 
public sector or nonprofit partner. Industrial consortia are included in this category. ${ }^{3}$

\section{Public or Mixed}

4. Supported spin-offs. These are recently established (less than 10 years from founding) firms started by technologists at universities or government labs who have been supported by federal research funds.

5. Government laboratories-working by themselves or in collaboration. Most of these innovations come from the federal laboratories run by the Department of Energy, but some come from NIH, military laboratories, and labs run by other agencies. If a university is a partner in one of these collaborations with a laboratory, it will be reported here and not under university.

6. Universities-working by themselves or in collaboration with entities other than federal labs.

7. Other public sector and non profit agencies-working by themselves or in collaboration with private firms.

\section{Analyzing the Data}

The R\&D awards data provide powerful evidence on all three research questions. We start with the second question-whether the shift towards collaboration has become a general trend. Analysts of the networked firm have argued that innovation increasingly results from collaborations between two or more organizations (Hargadon 2003; Lester and Piore 2004). The connections between knowledge embodied in one organization and the knowledge embodied in other organizations are critical for the innovation process. The sparks generated when these different approaches are combined facilitate the discovery of effective new approaches (Hargadon 2003). Our data provide support for this claim. Figure 1 shows a dramatic rise in the number of domestic award-winning innovations that involve inter-organizational collaborations. The number of innovations attributed to a single private sector firm operating alone averaged 67 in the 1970's, but that has dropped to an average of only 27 in the current decade.

\footnotetext{
3 We list any innovation as public as long as there is a collaborator that is public or a supported spinoff. We avoid double counting by listing collaborative winners under just one of these categories. If a government laboratory is a participant in a collaboration, the innovation is attributed to the laboratory regardless of other participants. If no government lab is involved, but there is a university, then the innovation is attributed to the university. If there is another public or nonprofit participant, the innovation is attributed to that participant. If there are multiple private participants, then it is coded in category 3-private collaboration. Table 1 in the Appendix provides sufficient detail to show that this particular coding scheme does not bias our results.
} 


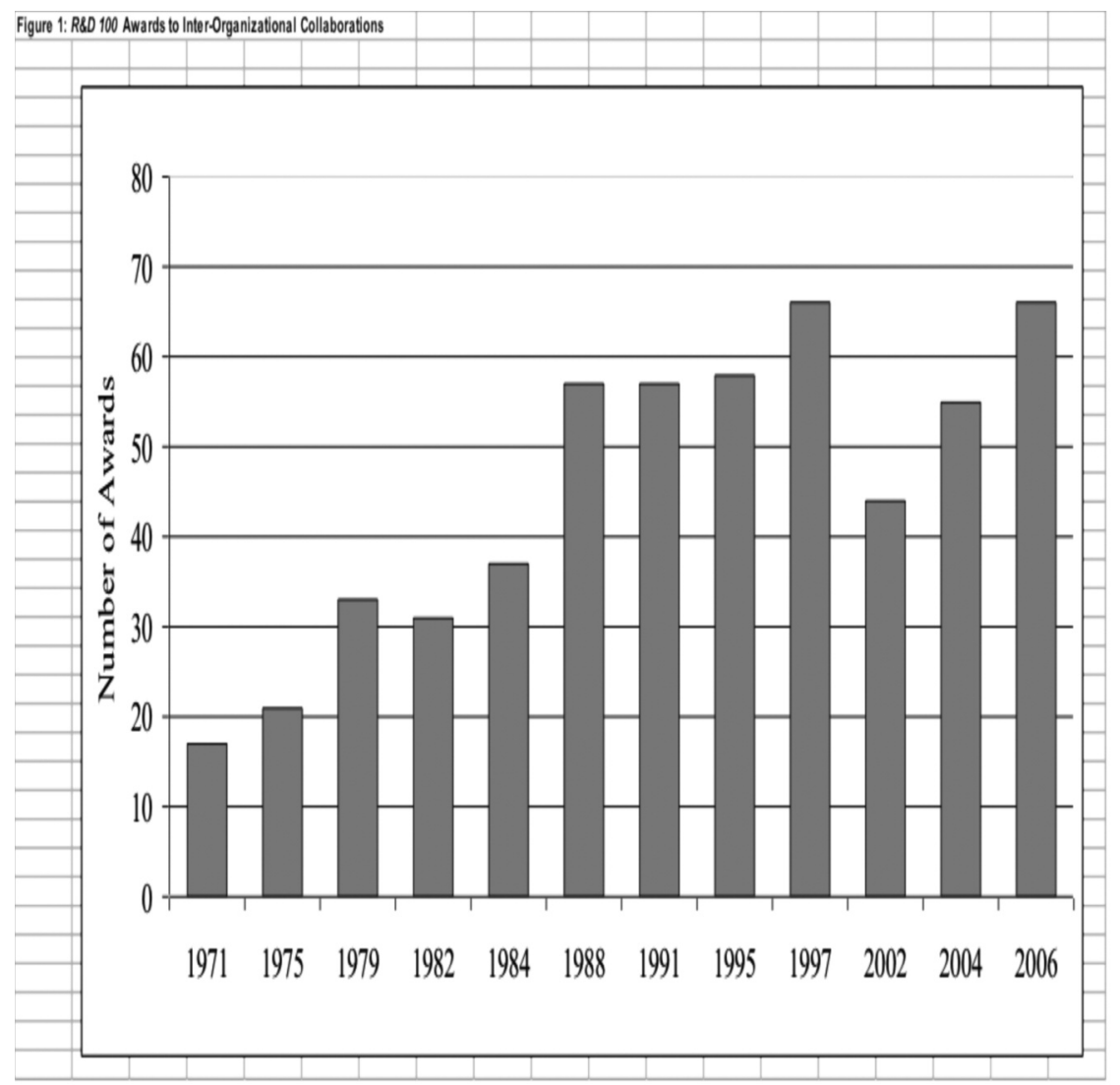

In part this shift reflects the growing importance of public sector agencies as award winners, since we code all public agencies as engaging in collaboration since they invariably employ private partners to market their innovative products. But it is also the case that even among the dwindling number of private sector winners, the frequency of formal collaborations rose from $7.8 \%$ in the 1970 's to $17.5 \%$ in the current decade.

An equally striking finding addresses the first research question - the role of large corporations in the innovation process. Figure 2 shows the dramatic decline in both solo and collaborative winners from the Fortune 500 firms. While these firms were the largest single winner of awards in the 1970's, by the current decade, solo winners from the Fortune 500 could be counted on the fingers of one hand. Even with collaborators, they averaged only ten awards per year. 


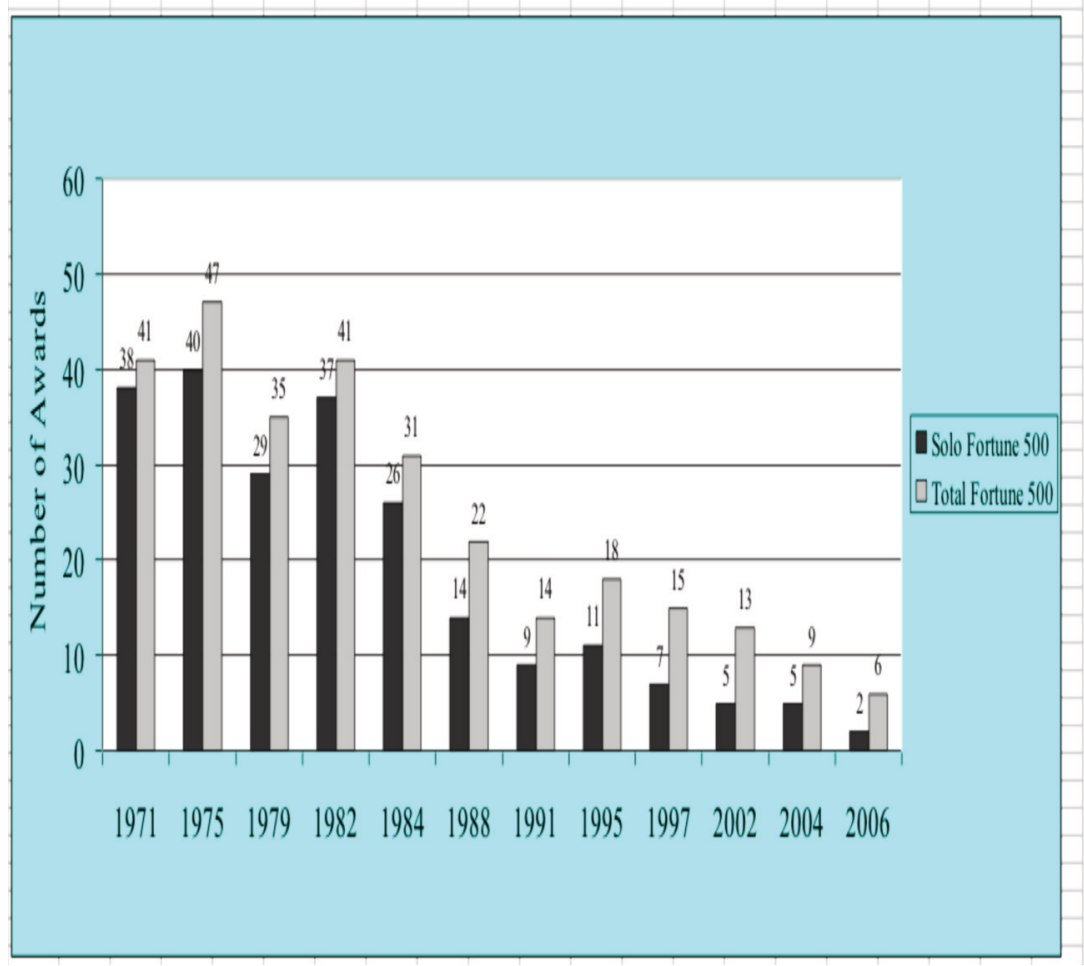

To be sure, this is the place where the almost total exclusion of large computer industry firms and pharmaceutical firms impacts the data. Data on U.S. patent applications shows that firms such as IBM, Microsoft, Intel, and Sun rank among the most prolific U.S. firms in the number of patents received (U.S. Patent and Trademark Office: http://www.uspto.gov/web/offices/ac/ido/ oeip/taf/reports.htm). They also represent important exceptions to the tendency for big firms to reduce their outlays for R\&D over the past twenty years. So the fact that their R\&D effort is only rarely recognized in the $R \& D 100$ means that Figure 2 overstates the declining innovative capacity of Fortune 500 firms. But even if the large computer industry firms were collectively receiving ten of these awards per year, Figure 2 would still show a significant downward trend.

The situation with pharmaceutical firms is more complicated. While the established large firms such as Merck and Pfizer and the most successful of the biotech firms such as Genentech and Amgen continue to fund significant research efforts, the number of innovative drugs they bring to the market in recent years has been quite limited. The drug industry has its own awards for innovation published by Prescrire International. ${ }^{4}$ Their highest

\footnotetext{
4 We are grateful to Donald Light for bringing these awards to our attention.
} 
award, the golden pill, recognizes new drugs that represent a major breakthrough. But between 1997 and 2006, only two drugs received this recognition and there were only twelve others that received second place recognition as a clear advance over existing therapies. This suggests that if the $R \& D 100$ competition had recognized prescription drugs, the results in Figure 2 would not have changed much at all.

The real significance of Figure 2 is the decline in awards won by general purpose manufacturing firms such as General Electric, General Motors, and 3M. Firms like these dominated the awards in the 1970's, but they only rarely win in recent years. This decline parallels the trend in their patenting activity, strongly suggesting diminished innovative efforts. Figure 3 shows a dramatic decline in the percentage of U.S. corporate patents won by nine of these manufacturing firms that have been in continuous existence and are outside the computer industry.

\section{Figure 3: Percent of Total U.S. Corporate Patents Received by GE, Kodak, AT\&T, DuPont, GM, Dow Chemical, 3M, United Technologies, and Ford, 1971.2006}

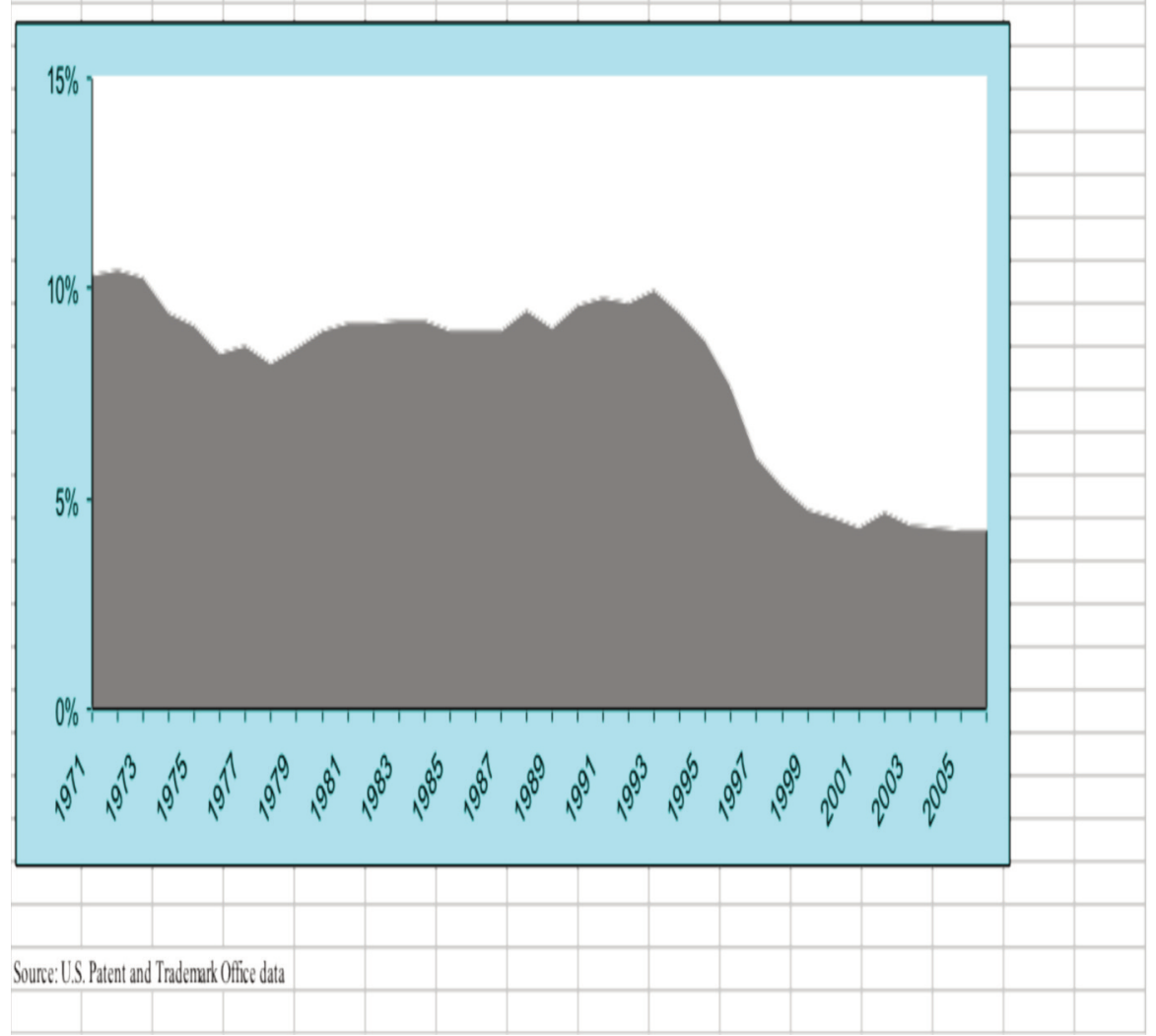


These declines can be traced to the priorities of corporate executives faced with continuing pressure over the last several decades to improve the quarterly financial results of their firms. Many firms have cut back their R\&D efforts or shifted funds towards product development. After all, research is expensive and its contribution to the bottom line is likely to come long after the current CEO's tenure in office. At the same time, the financial orientation of top executives means that they see new technologies as simply another asset that can be acquired rather than produced internally. They are confident that when the time comes, they can either license the technologies they need or buy up the firms that are producing innovations (Estrin 2009; Tassey 2007).

The magnitude of this shift is indicated by employment trends among scientists and engineers working for private firms. According to data collected by the NSF, in $19717.6 \%$ percent of R\&D scientists and engineers working for industry, or 28,200 individuals, were employed by firms with fewer than 1,000 employees. By 2004, this percentage had risen to $32 \%$, while the actual number of people had grown to 365,000 . NSF data also indicate that Ph.D. scientists and engineers have become even more concentrated in small firms; in 2003, $24 \%$ of those working for industry were employed at firms with fewer than ten employees and more than half were at firms with under 500 employees. ${ }^{5}$ It is, of course, impossible to know how much of this shift reflected push factors that led technologists to leave large firms and how much was the attraction of working in smaller firms. Either way, the trend in the awards away from big firms follows the trend of the technologists who create the innovations.

As the role of large corporations declined, there has been a corresponding gain in awards for public and mixed entities. This provides answers to the third research question-whether the public sector is playing an expanding role in the innovation system. As Figure 4 shows, the majority of awards are now won by either federal laboratories, universities, or the firms that we have categorized as supported spinoffs. In the last two decades, the federal laboratories have become the dominant organizational locus for wining these awards. They now have about the same weight in the overall awards as the Fortune 500 firms did in the 1970 's-averaging about 35 awards per year. ${ }^{6}$ This is a surprising finding because many observers hold the federal laboratories in low

\footnotetext{
5 “Number of full-time-equivalent (FTE) R\&D scientists and engineers in R\&D-performing companies, by industry and by size of company" is available at http://www.nsf.gov/statistics/iris/search hist.cfm?indx $=24$ and http://www.nsf.gov/statistics/nsf07314/pdf/tab41.pdf. These figures should be taken as approximations due to changes in NSF's procedures for collecting and estimating this data over time. Data on Ph.D employees are provided in figure 3.18 in Science and Engineering Indicators, 2008 at http://www.nsf.gov/statistics/seind08/figures.htm.

6 In the cases that we have coded as solo, the innovation award went solely to a federal lab or a university. This presumably indicates that the partner enlisted to commercialize the product had no ownership of the intellectual property involved in the innovation.
} 
esteem and doubt their capacity to contribute to innovation. Most of the winning innovations originate in the Department of Energy laboratories that were initially created to develop atomic weapons in the early years of the Cold War. The sinister image of Ph.D. physicists and chemists working assiduously to develop ever more destructive weaponry has certainly colored the public image of these facilities. ${ }^{7}$

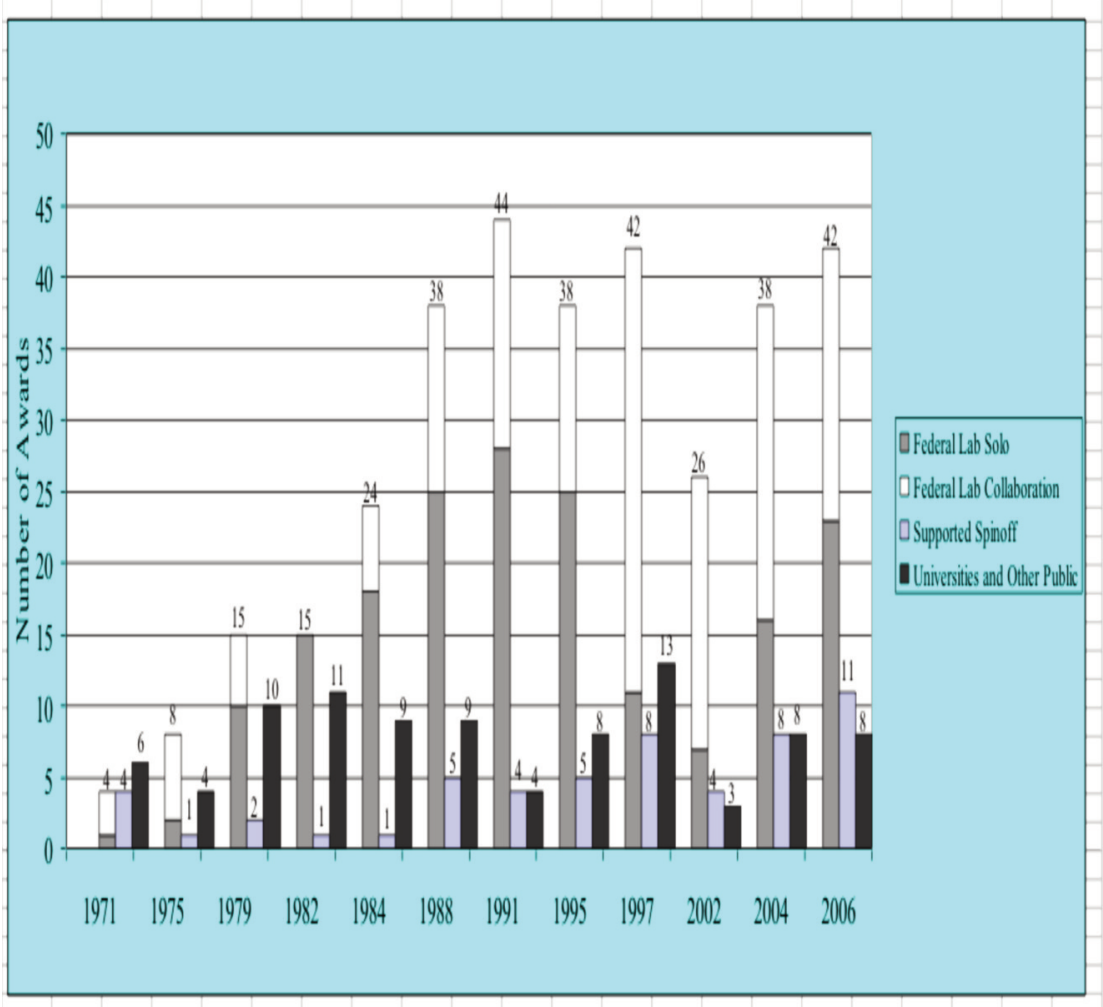

After the Federal laboratories, the next most important public or mixed entity are the supported spin-offs. These entities-on their own-averaged close to eight awards per year in the current decade and they also win some additional awards in partnership with government laboratories or universities. Moreover, as we will see later, firms that began as supported spin-offs but have been in existence for more than ten years are coded as "other firms" - part of the private category-and their weight in the awards has also increased over time.

\footnotetext{
7 Even in the scholarly literature, it is rare to find recognition of the innovation productivity of the labs. For an overview of the labs, see Crow and Bozeman 1998. One of the rare sources that recognizes the increased commercial productivity of the labs is Jaffe and Lerner 2001.
} 
The typical pattern of a supported spin-off is that a professor or a scientist at a university or federal laboratory makes an important discovery and consults with university or lab officials as to how best to protect the resulting intellectual property. In many cases, the organization encourages the innovator to start his or her own firm to develop and ultimately market the new product. The more entrepreneurial universities and laboratories function almost as venture capitalists by helping the individual find investors and experienced managers who could guide the firm (Geiger and Sa 2008).

The final category in Figure 4 encompasses awards won by universities and other public sector agencies and nonprofit firms. Surprisingly, the direct weight of universities among award winners is relatively modest. There are several reasons for this. First, some innovations that originate in university laboratories show up in the supported spinoffs category because the researcher started his or her own firm. Second, university-based researchers are increasingly part of collaborations with federal laboratories and our coding system attributes those innovations to the labs. In 2006, for example, universities received two awards in partnership with other firms and seven in partnership with federal laboratories. In short, even though the importance of scientific discoveries at universities has become ever more central to the innovation process, most of the transition into commercial products is mediated through spinoffs and the activities at federal laboratories. ${ }^{8}$

Yet a focus on organizational auspices alone does not capture the full extent of U.S. government financing of the innovation process. Figure 5 shows the role of one of the most important-but little known-federal programs: the Small Business Innovation Research (SBIR) program. Firms that had previously received one or more SBIR awards represent a very large share of winners in the current decade. SBIR is a set aside program which requires that federal agencies with large research budgets devote $2.5 \%$ of their R\&D budgets to support firms with 500 employees or less. It is also a program that provided initial funding for many of the supported spinoffs. The program awards up to $\$ 100,000$ in no strings support for projects in Phase I and up to $\$ 750,000$ for Phase II projects that have shown significant progress in meeting the initial objectives. ${ }^{9}$ In 2004 , the SBIR project gave out more than $\$ 2$ billion for some sixty-three hundred separate research projects. As the figure shows, current and past SBIR award winners have come to constitute roughly $25 \%$ of domestic winners each year.

\footnotetext{
8 Even if we recode collaborations that involve both a federal lab and a university as "university," the number of award-winning innovations involving federal labs still substantially outweighs those involving universities.

9 The NIH has applied for and received a waiver which enables it to exceed these caps.
} 


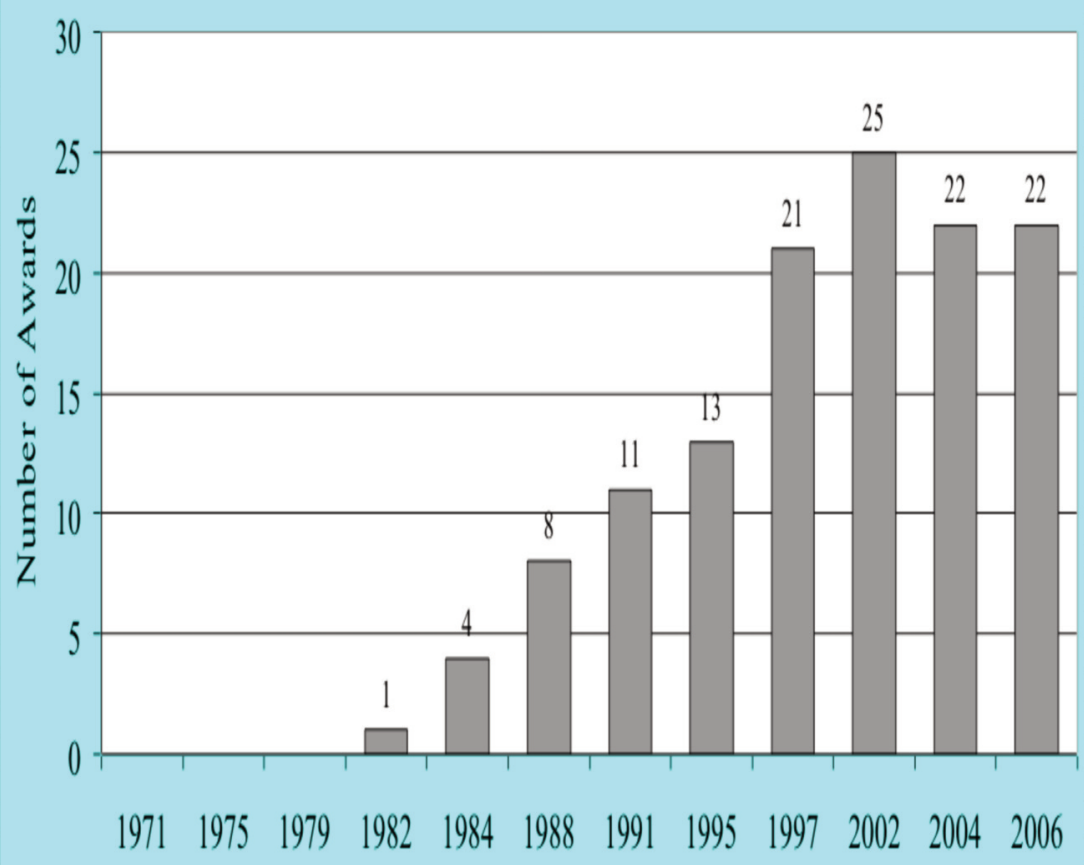

Note: the singe fim listed in 1982, Radiation Monitoring Devices, received funding from the SBR precursor program, a pilot project operated under the auspices of NSF

In Figure 6, we try to provide a more comprehensive measure of the role of federal financing over time by looking in greater detail at funding for award winners in 1975 and 2006. The bottom part of each graph shows the various public sector winners that rely heavily on federal funding. As indicated earlier, this shows a dramatic rise from 14 to 61 of the awardees. But the top part of the graph shows the number of "other" and Fortune 500 firms that received at least $1 \%$ of their revenues from the federal government. ${ }^{10}$ This $1 \%$ screen picks up both large defense contractors as well as firms that have received substantial federal grants to support their R\&D efforts. In 1975, there were 23 awards won by private firms who received at least $1 \%$ of their revenues from federal support. Prominent among these was General Electric

10 The logic of using a $1 \%$ of revenue screen is that it is common among large firms to devote only 3 to $4 \%$ of revenues to $R \& D$ expenditures. Hence federal awards or contracts of that magnitude could help fund a significant increase in $R \& D$ effort. 
which in that year was responsible for nine award winning innovations. ${ }^{11}$

In 2006, we found that of five private collaborations, the federal government directly funded three. Of the 20 "other firms" that won awards, 13 had federal support above the $1 \%$ threshold and we were able to link the federal money directly to the specific innovation that received the award. Hence, sixteen of these "private" innovations count as federally funded. The overall result in Figure 6 is that the number of federally funded innovations rises from 36 in 1975 to 77 in 2006.

In 2006, literally only eleven of the domestic award winners were not beneficiaries of federal funding. Two winning firms - Brion Tech and MMR Technologies - were recent spinoffs from Stanford University, but they had not received federal funding after their launch. In short, Figure 6 probably understates the magnitude of the expansion in federal funding for innovations between 1975 and 2006. After all, in 1975, we count innovations as federally funded even if support was not going to the specific unit of the firm that was working on a particular innovation. For 2006, however, a demonstration of federal support required showing that the federal funds were going to the same unit that was responsible for the particular technology that won the award.

Figure 6: Winners Receiving Federal Dollars

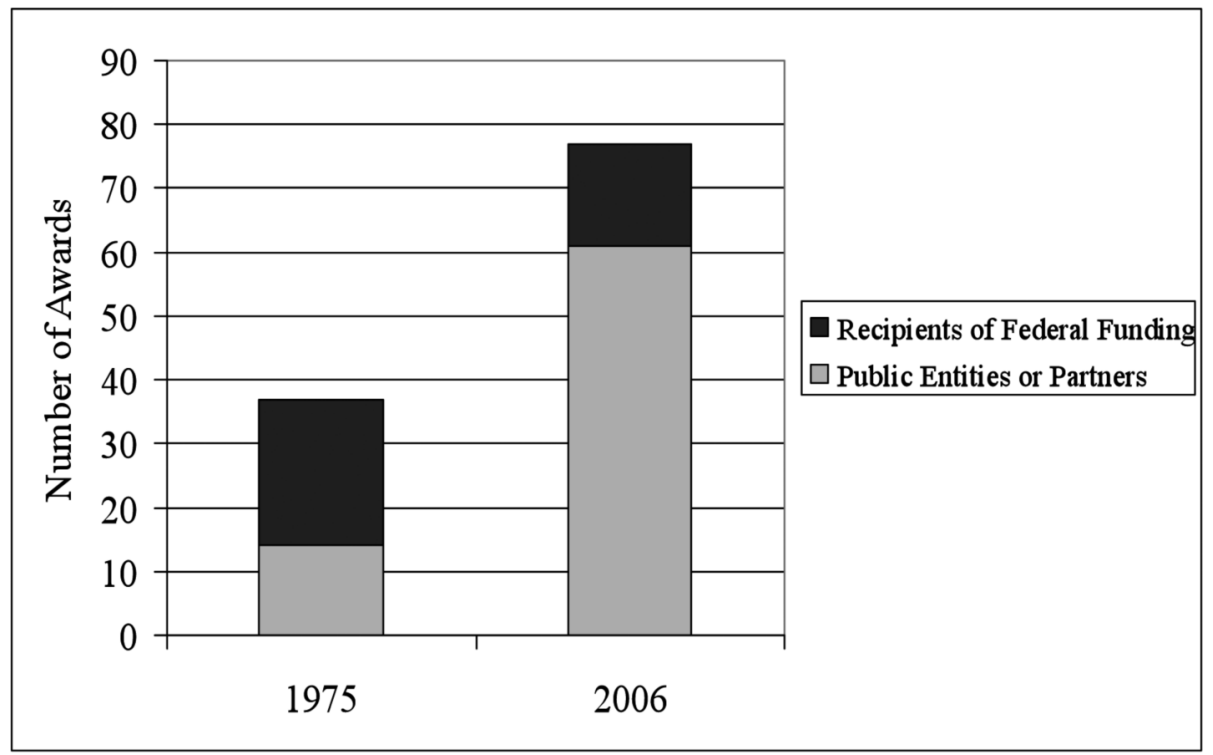

11 There were five additional awards that went to Fortune 500 companies that had contracts to manage government laboratories in 1975 - two each for Union Carbide and DuPont and one for Monsanto. 
Even in the period that Fortune 500 corporations dominated the innovation process, they drew heavily on federal funding support. If one is looking for a golden age in which the private sector did most of the innovating on its own without federal help, one has to go back to the era before World War II (Hounshell 1996). Nevertheless, over the last forty years, the awards indicate a dramatic increase in the federal government's centrality to the innovation economy. In the earlier period, U.S. industrial and technology policies were almost entirely monopolized by the military and space programs (Alic 2007; Hooks 1990). More recently, a wide range of non-defense agencies are involved in supporting private sector research and development initiatives. Key agencies now include Commerce, Energy, NIH, Agriculture, NSF, and Homeland Security.

\section{Discussion}

Our data set provides evidence of three interrelated changes in the U.S. economy over the past generation. These are the declining centrality of the largest corporations to the innovation process in the U.S., the growing importance of inter-organizational collaboration and small startup firms in the innovation process, and the expanded role of public sector institutions as both participants in and funders of the innovation process.

It is the last of these shifts that is the most surprising since this change coincided with the period in which market fundamentalist ideas dominated public policy debates. But it is important to recognize how different the federal role is from models of centrally planned technological change. In Chalmers Johnson's (1982) classic account of the Japanese model of industrial policy, he shows how government officials, working at the Ministry of Trade and Industry, operated as both coordinators and financiers for the conquest of new markets by Japanese firms. The key was that the government officials were implementing a shared plan that linked investments in particular technologies with specific business strategies to win in particular markets-both domestically and internationally.

In the U.S. case, there is no unified plan and different government agencies engage in support for new technologies often in direct competition with other agencies. The approach is more like Mao's “let a hundred flowers bloom": the U.S. has created a decentralized network of publicly funded laboratories where technologists have strong incentives to work with private firms and find ways to turn their discoveries into commercial products. Moreover, an alphabet soup of different programs provides agencies with opportunities to fund some of these more compelling technological possibilities.

Alongside this "build it and they will come" approach, there are also targeted government programs that are designed to accelerate progress across specific technological barriers. However, these programs are also imple- 
mented in a decentralized fashion by small agencies. The model developed by DARPA of setting technological goals and working closely with researchers to accelerate breakthroughs has now diffused across the federal system (Block 2008).

But because these programs contradict the market fundamentalist ideology that celebrates private enterprise and denigrates the public sector, they have remained largely unknown to the public. Journalists rarely write about government technology initiatives; for example, The New York Times has mentioned the SBIR program in its news coverage fewer than ten times over the last 27 years. To be sure, Congress periodically debates the design and funding for these programs, but reports on these discussions are rarely covered in The Wall Street Journal or general purpose business publications. Since the programs are largely unknown, they simply do not figure in public policy debates (Block 2008).

Ironically, the parameters of these little known state programs fit the model of a Developmental Network State (DNS) that Sean Ó Riain (2004) elaborated in his study of the Irish government's efforts to encourage high tech growth in that nation (see also Breznitz 2007). Just as in Ó Riain's case, government efforts are highly decentralized, rely on strengthening technological networks that cut across the public-private divide, and require public sector officials to play a multiplicity of roles in supporting entrepreneurial efforts.

Recently, Whitford and Schrank (2011) have usefully conceptualized these government programs as efforts to overcome failures that are endemic in networked forms of economic organization. In contrast to market failures, network failures occur when economic actors are unable to find appropriate network partners who are both competent and trustworthy.

The programs of a Developmental Network State help to stitch together networks and work to improve and validate the competence of potential network partners. Furthermore, the federal laboratories, industry-university research centers sponsored by the NSF, and informal meetings sponsored by agencies such as DARPA create "collaborative public spaces" (Lester and Piore 2004) where network participants are able to share key ideas.

But this revised understanding of how innovation is organized in the U.S. economy has important implications for the regime governing intellectual property rights. The growing interdependence between private firms and researchers at university and government laboratories make it imperative to rethink the assumptions on which intellectual property rules rest. The old rules rest on the old distinction between basic science and applied science. With basic science, researchers are supposed to publish their findings so they can be replicated and everyone understands the need for openness and 
the sharing of information. But with applied science where there are clear commercial applications, it is simply assumed that researchers should be able to protect the intellectual property they generate.

While the divide between basic and applied science has always been problematic (Stokes 1997), it now no longer makes any sense at all. Basic scientific discoveries such as breakthroughs in molecular biology rapidly generate commercial applications, and work on such applied problems as conquering particular diseases routinely generate basic scientific discoveries. The growing interdependence between university and federal laboratory scientists and private firms is a manifestation of the obsolescence of this distinction.

One response to the disappearance of this boundary is to redefine all scientific inquiry as potentially having commercial applications so that all practitioners are urged to establish and protect their discoveries as valuable intellectual property. This is the direction that was signaled by the Supreme Court in its 1980 Diamond vs. Chakrabarty decision approving a patent for a genetically modified organism. But this path threatens the very survival of the scientific project which is built on creating shared knowledge and prioritizing publication as the key to individual scientific careers.

The opposite and far more constructive response is to stretch the scientific norms that include the free flow of information and knowledge deep into the realm of applied science. This could be done by making the patent system more like it was in the U.S. in the first half of the $19^{\text {th }}$ century when innovators had to provide a physical model of their new idea. In other words, patents would be limited to something holistic and close to a commercial product, not on dozens of small components and processes that were combined into a finished product. This is the approach that fits best with our findings about the networked nature of contemporary innovation.

As we have seen, collaboration among firms is now essential to the innovation process, but firms have to worry that collaborators might steal the valuable intellectual property that their researchers have already produced. The resulting distrust is a major source of network failure. This is precisely why the collaborative public spaces provided by federal and university laboratories loom so large in our study of the R\&D 100 awards. These settings provide a safe place where scientists and engineers - including those working at private firms - can work together with a much reduced danger that their ideas will be unfairly appropriated by others. But shifting the patent regime to protect only holistic designs would help encourage collaboration and reduce distrust. ${ }^{12}$

\footnotetext{
12 It would also address the huge backlog problem faced by patent offices that cannot keep up with the rapid flow of new patent applications.
} 
A concrete example is helpful. One of the current technological holy grails is the development of a new generation of lithium ion batteries that would generate more voltage for a significantly reduced battery weight. Drawing on nanotechnology, many scientists are currently experimenting with different patterns and different materials for the key elements of this battery. Under current patent law, there literally could be hundreds or even thousands of distinct patents to cover production processes for distinct parts of the battery. Our alternative idea is that a single patent would be granted for a new more effective battery design that included descriptions of the novel techniques used to reach the higher efficiencies. Other firms would have to pay license fees if they drew heavily on that design until a new breakthrough enabled another quantum leap in battery effectiveness which could, in turn, be protected by a patent.

\section{Conclusion}

The current systems of intellectual property protection were developed for a very different innovation environment than that which currently exists. In an era where most innovations were produced by corporate laboratories or individual inventors, the existing patent system made sense. But since innovation now occurs in collaborative networks, often linking the public and private sectors, the existing patent system has often become a significant barrier to scientific and technological advance. In the computer industry, patents are widely considered to be simply a nuisance that large firms manage by acquiring large portfolios of patents that they use defensively when they are accused of infringement. In the biomedical area, university-based researchers sometimes find themselves restricted from pursuing a line of research because some other entity has property rights in a particular organism or genetic sequence. And business firms must be constantly alert to the danger that their collaborators might appropriate their intellectual property and get to the patent office first.

The situation is further complicated by the growing role of the public sector in financing much of the research that produces commercially valuable intellectual property. A study by Vallas, Kleinman, and Biscotti (2011) shows that many of the highest selling biotechnology drugs were developed with substantial research financing by the U.S. government. Pharmaceutical firms often sell these products at extremely high prices and generate large profits, but there is no specific payback to the government for its earlier contribution. This problem now exists in milder forms across much of the economy.

All this suggests the need for serious rethinking of the current framework for the protection of intellectual property. A new regime of knowledge governance is necessary to recognize the important role of the public sector in 
facilitating innovation and to minimize the negative consequences on technological advance of the current restrictive regime of intellectual property rights. To be sure, there is still a need to protect and provide proper incentives for those who help to develop innovative new products, but this could be done within a very different set of rules from those that have been inherited from the recent past. 


\section{References}

Alic, John. 2007. Trillions for Military Technology. New York: Palgrave.

Arrighi, Giovanni. 2007. Adam Smith in Beijing: Lineages of the $21^{\text {st }}$ Century. London: Verso.

Bell, Daniel. 1973. The Coming of Post-Industrial Society. New York: Basic Books.

Bennis, Warren and Philip Slater. 1968. The Temporary Society. New York: Harper \& Row

Block, Fred. 1990. Postindustrial Possibilities. Berkeley: University of California Press.

- - - - - - - 2008. "Swimming Against the Current: The Rise of a Hidden Developmental State in the United States." Politics \& Society.

Breznitz, Dan. 2007. Innovation and the State: Political Choice and Strategies for Growth in Israel, Taiwan, and Ireland. New Haven: Yale University Press.

Brick, Howard. 2006. Transcending Capitalism: Visions of a New Society in Modern American Thought. Ithaca: Cornell University Press.

Burns, Tom and G.M. Stalker. 1961. The Management of Innovation. London: Tavistock.

Collins, Steven. 2004. The Race to Commercialize Biotechnology. New York: RoutledgeCurzon.

Crow, Michael and Barry Bozeman. 1998. Limited by Design: R\&D Laboratories in the U.S. National Innovation System. New York, Columbia University Press.

Estrin, Judy. 2009. Closing the Innovation Gap: Reigniting the Spark of Creativity in a Global Economy. New York: McGraw Hill.

Etzkowitz, Henry. 2003. "Innovation in Innovation: The Triple Helix of University-Industry-Government Relations." Social Science Information 42:293-337.

Fligstein, Neil. 1990. The Transformation of Corporate Control. Cambridge: Harvard University Press.

Fong, Glenn R. 2000. "Breaking New Ground or Breaking the Rules: Strategic Reorientation in U.S. Industrial Policy." International Security 25:2 (August): 152-186.

Geiger R., Sa C. 2008 Tapping the Riches of Science: Universities and the Promise of Economic Growth. Cambridge, MA: Harvard University Press.

Gordon, David, Richard Edwards, and Michael Reich. 1982. Segmented Work, Divided Workers: The Historical Transformation of Labor in the United States. New York: Cambridge University Press.

Hargadon, Andrew. 2003. How Breakthroughs Happen: The Surprising Truth About How Corporations Innovate. Boston: Harvard Business School Press. 
Hooks, Gregory. 1990. "The Rise of the Pentagon and U.S. State Building: The Defense Program as Industrial Policy." American Journal of Sociology 96:2 (September): 358-404.

Hounshell, David. 1996. "The Evolution of Industrial Research in the United States." Pp. 13-85 in Rosenbloom and Spencer, eds., Engines of Innovation.

Jaffe, Adam and Josh Lerner. 2001. "Reinventing Public R\&D: Patent Policy and the Commercialization of National Laboratory Technologies." Rand Journal of Economics (March).

Johnson, Chalmers. 1982. MITI and the Japanese Miracle. Stanford: Stanford University Press.

Kenney, Martin. 1986. Biotechnology: The University-Industrial Complex. New Haven: Yale University Press.

Kevles, Daniel. 1992. "Out of Genetics: The Historical Politics of the Human Genome." Pp. 3-36 in Daniel Kevles and Leroy Hood, eds., The Code of Codes: Scientific and Social Issues in the Human Genome Project. Cambridge: Harvard University Press.

Kotz, David. M., Terence McDonough, and Michael Reich. Eds. 1994. Social Structures of Accumulation: The Political Economy of Growth and Crisis. New York: Cambridge University Press.

Larson, Magali Sarfatti. 1993. Behind the Postmodern Façade. Berkeley: University of California Press

- - - - - - - . 1994. "Architectural Competitions as Discursive Events." Theory and Society 23:4 (August): 469-504.

Lerner, Josh. 1999. "When Bureaucrats Meet Entrepreneurs: The Design of Effective 'Public Venture Capital' Programmes." The Economic Journal. 112:477 (February): 73-84.

Lester, Richard and Michael J. Piore. 2004. Innovation: The Missing Dimension. Cambridge, Mass.: Harvard University Press.

Lundvall, B.-A. 1992. National Systems of Innovation: Towards a Theory of Innovation and Interactive Learning. London: Pinter.

McCray, W. Patrick. 2009. "From Lab to iPod: A Story of Discovery and Commercialization in the Post-Cold War Era." 50:1 (January): 58-81.

Mowery, David C. 2009. "Plus ca Change: Industrial R\&D in the "Third Industrial Revolution." Industrial and Corporate Change 18:1 (February): 1-50.

Mowery, David C., Richard Nelson, Bhaven Sampat, and Arvids Ziedonis. 2001. Ivory Tower and Industrial Innovation. Stanford: Stanford Business.

Nelson, Richard. ed. 1993. National Innovation Systems: A Comparative Analysis. New York: Oxford University Press.

Newfield, Christopher. 2008. Unmaking the Public University: The Forty Year Assault on the Middle Class. Cambridge: Harvard University Press.

Ó Riain, Sean. 2004. The Politics of High-Tech Growth: Developmental Net- 
work States in the Global Economy. Cambridge: Cambridge University Press.

Powell, Walter. 2001. "The Capitalist Firm in the Twenty-First Century: Emerging Patterns in Western Enterprise." Pp. 33-68 in Paul DiMaggio, ed., The Twenty-First Century Firm. Princeton: Princeton University Press.

Powell, Walter, Douglas White, Kenneth Koput, and Jason Owen-Smith. 2005. "Network Dynamics and Field Evolution: The Growth of Interorganizational Collaboration in the Life Sciences." American Journal of Sociology 110: 1132-1205.

Prescrire International. 2007. "Prescrire Awards." 16:88 (April) 76.

Roessner, David, Barry Bozeman, Irwin Feller, Christopher Hill, and Nils Newman. 1997. The Role of NSF Support of Engineering in Enabling Technological Innovation. Stanford: SRI Policy Division.

Roland, Alex with Philip Shiman. 2002. Strategic Computing: DARPA and the Quest for Machine Intelligence 1983-1993. Cambridge, Mass.: MIT Press.

Rosenbloom, Richard and William J. Spencer. Eds. 1996. Engines of Innovation: U.S. Industrial Research at the End of an Era. Boston: Harvard Business School Press.

Saxenian, AnnaLee. 1994. Regional Advantage: Culture and Competition in Silicon Valley and Route 128. Cambridge: Harvard University Press.

Sciberras, E. 1986. "Indicators of Technical Intensity and International Competitiveness: A Case for Supplementing Quantitative Data with Qualitative Studies in Research." R\&D Management 16:1 (May): 3-14.

Slaughter, Sheila and Gary Rhoades. 2002. "The Emergence of a Competitiveness Research and Development Policy Coalition and the Commercialization of Academic Science and Technology." Pp. 69-108 in Philip Mirowski and Esther Mirjam Sent, eds., Science Bought and Sold: Essays in the Economics of Science. Chicago: University of Chicago Press.

Stokes, Donald. 1997. Pasteur's Quadrant: Basic Science and Technological Innovation. Washington: Brookings.

Tassey, Gregory. 2007. The Technology Imperative. Cheltenham, U.K.: Edward Elgar.

Taylor, Mark Zachary. 2004. “Empirical Evidence Against Variety of Capitalism's Theory of Technological Innovation." International Organization 58 (Summer): 601-631.

Thursby, J.G. and M.C. Thursby. 2002. "Who is Selling the Ivory Tower:? Sources of Growth in University Licensing." Management Science 48 (1): 123-144.

Vallas, Steven P., Daniel Lee Kleinman, and Dina Biscotti. 2011. "Political Structures and the Making of U.S. Biotechnology." Pp. 57-76 in Fred Block and Matthew R. Keller, eds., State of Innovation: The 
U.S. Government's Role in Technology Development. Boulder: Paradigm.

Weiss, Linda and Elizabeth Thurbon. 2006. "The Business of Buying American: Public Procurement as Trade Strategy in the United States." Review of International Political Economy 13:5:701-724.

Whitford, Josh. 2005. The New Old Economy: Networks, Institutions, and the Organizational Transformation of American Manufacturing. New York: Oxford University Press.

Whitford, Josh and Andrew Schrank. 2011. "The Paradox of the Weak State Revisited; Industrial Policy, Network Governance, and Political Decentrlaization." Pp. 261-281 in Fred Block and Matthew R. Keller, eds., State of Innovation: The U.S. Government's Role in Technology Development." Boulder, Colorado: Paradigm Publishers. 
Appendix 1: Composition of R\&D 100 Award Winners

\begin{tabular}{|c|c|c|c|c|c|c|c|c|c|c|c|c|}
\hline & 1971 & 1975 & 1979 & 1982 & 1984 & 1988 & 1991 & 1995 & 1997 & 2002 & 2004 & 2006 \\
\hline Total Awards & 102 & 98 & 100 & 100 & 100 & 100 & 98 & 101 & 100 & 97 & 94 & 100 \\
\hline Total Foreign & 5 & 12 & 10 & 14 & 14 & 11 & 13 & 12 & 12 & 14 & 10 & 12 \\
\hline Total Domestic & 97 & 86 & 90 & 86 & 86 & 89 & 85 & 89 & 88 & 83 & 84 & 88 \\
\hline \multicolumn{13}{|l|}{$\begin{array}{l}\text { Of Domestic } \\
\text { Award Winners }\end{array}$} \\
\hline \multicolumn{13}{|l|}{ Private } \\
\hline $\begin{array}{l}\text { 1. Fortune } \\
500 \text { Alone }\end{array}$ & 38 & 40 & 29 & 37 & 26 & 14 & 9 & 11 & 7 & 5 & 5 & 2 \\
\hline $\begin{array}{l}\text { 2. Other Firms } \\
\text { Alone }\end{array}$ & 42 & 25 & 28 & 18 & 23 & 18 & 20 & 20 & 15 & 34 & 24 & 20 \\
\hline $\begin{array}{l}\text { 3. Private } \\
\text { Consortia }\end{array}$ & 3 & 8 & 6 & 4 & 3 & 5 & 4 & 7 & 3 & 11 & 1 & 5 \\
\hline $\begin{array}{l}\text { Includes F-500 } \\
\text { Firm }\end{array}$ & 1 & 2 & 4 & 3 & 1 & 4 & 1 & 4 & 1 & 7 & 1 & 0 \\
\hline Sub-Total & 83 & 73 & 63 & 59 & 52 & 37 & 33 & 38 & 25 & 50 & 30 & 27 \\
\hline \multicolumn{13}{|l|}{$\begin{array}{l}\text { Public or } \\
\text { Quasi-Public }\end{array}$} \\
\hline $\begin{array}{l}\text { 4. Supported } \\
\text { Spin-offs }\end{array}$ & 4 & 1 & 2 & 1 & 1 & 5 & 4 & 5 & 8 & 4 & 8 & 11 \\
\hline $\begin{array}{l}\text { 5. Government } \\
\text { labs }\end{array}$ & 4 & 8 & 15 & 15 & 24 & 38 & 44 & 38 & 42 & 26 & 38 & 42 \\
\hline Solo Credit & 1 & 2 & 10 & 15 & 18 & 25 & 28 & 25 & 11 & 7 & 16 & 23 \\
\hline$w / F-500$ & 1 & 5 & 2 & $O$ & 3 & 4 & 4 & 3 & 5 & 1 & 2 & 3 \\
\hline$w /$ University & 0 & 0 & 0 & 0 & 1 & 2 & 4 & 2 & 3 & 2 & 5 & 7 \\
\hline w/others & 2 & 1 & 3 & 0 & 2 & 7 & 9 & 8 & 23 & 16 & 15 & 9 \\
\hline 6. Universities & 3 & 0 & 4 & 4 & 1 & 1 & 1 & 5 & 6 & 2 & 4 & 2 \\
\hline Solo Credit & 1 & 0 & 4 & 1 & 1 & 1 & 1 & 1 & 2 & 0 & 1 & 0 \\
\hline$w / F-500$ & 1 & 0 & 0 & 0 & 0 & 0 & 0 & 0 & 0 & 0 & 0 & 0 \\
\hline w/others & 1 & 0 & 0 & 3 & 0 & 0 & 0 & 4 & 4 & 2 & 3 & 2 \\
\hline 7. Other public & 3 & 4 & 6 & 7 & 8 & 8 & 3 & 3 & 7 & 1 & 4 & 6 \\
\hline$w / F-500$ & 0 & 0 & 0 & 1 & 1 & 0 & 0 & 0 & 2 & 0 & 1 & 1 \\
\hline Sub-Total & 14 & 13 & 27 & 27 & 34 & 52 & 52 & 51 & 63 & 33 & 54 & 61 \\
\hline Total F-500 & 41 & 47 & 35 & 41 & 31 & 22 & 14 & 18 & 15 & 13 & 9 & 6 \\
\hline
\end{tabular}




\section{Working Papers in Technology Governance and Economic Dynamics}

The Other Canon Foundation, Norway, and the Technology Governance program at Tallinn University of Technology (TUT), Estonia, have launched a new working papers series, entitled "Working Papers in Technology Governance and Economic Dynamics". In the context denoted by the title series, it will publish original research papers, both practical and theoretical, both narrative and analytical, in the area denoted by such concepts as uneven economic growth, techno-economic paradigms, the history and theory of economic policy, innovation strategies, and the public management of innovation, but also generally in the wider fields of industrial policy, development, technology, institutions, finance, public policy, and economic and financial history and theory.

The idea is to offer a venue for quickly presenting interesting papers scholarly articles, especially as preprints, lectures, essays in a form that may be developed further later on - in a high-quality, nicely formatted version, free of charge: all working papers are downloadable for free from http://hum.ttu.ee/tg as soon as they appear, and you may also order a free subscription by e-mail attachment directly from the same website.

The first nine working papers are already available from the website.

They are

1. Erik S. Reinert, Evolutionary Economics, Classical Development Economics, and the History of Economic Policy: A Plea for Theorizing by Inclusion.

2. Richard R. Nelson, Economic Development from the Perspective of Evolutionary Economic Theory.

3. Erik S. Reinert, Development and Social Goals: Balancing Aid and Development to Prevent 'Welfare Colonialism'.

4. Jan Kregel and Leonardo Burlamaqui, Finance, Competition, Instability, and Development Microfoundations and Financial Scaffolding of the Economy.

5. Erik S. Reinert, European Integration, Innovations and Uneven Economic Growth: Challenges and Problems of EU 2005.

6. Leonardo Burlamaqui, How Should Competition Policies and Intellectual Property Issues Interact in a Globalised World?

A Schumpeterian Perspective

7. Paolo Crestanello and Giuseppe Tattara, Connections and Competences in the Governance of the Value Chain. How Industrial Countries Keep their Competitive Power

8. Sophus A. Reinert, Darwin and the Body Politic: Schäffle, Veblen, and the Shift of Biological Metaphor in Economics 
9. Antonio Serra, Breve Trattato / A Short Treatise (1613) (available only in hardcopy and by request).

10. Joseph L. Love, The Latin American Contribution to CenterPeriphery Perspectives: History and Prospect

11. Ronald Dore, Shareholder capitalism comes to Japan

12. Per Högselius, Learning to Destroy. Case studies of creative destruction management in the new Europe

13. Gabriel Yoguel, Analía Erbes, Verónica Robert, and José Borello, Diffusion and appropriation of knowledge in different organizational structures

14. Erik S. Reinert and Rainer Kattel, European Eastern Enlargement as Europe's Attempted Economic Suicide?

15. Carlota Perez, Great Surges of development and alternative forms of globalization

16. Erik S. Reinert, lulie Aslaksen, Inger Marie G. Eira, Svein Mathiesen, Hugo Reinert \& Ellen Inga Turi, Adapting to Climate Change in Reindeer Herding: The Nation-State as Problem and Solution

17. Lawrence King, Patrick Hamm, The Governance Grenade: Mass Privatization, State Capacity and Economic Development in Postcommunist and Reforming Communist Societies

18. Reinert, Erik S., Yves Ekoué Amaïzo and Rainer Kattel. The Economics of Failed, Failing and Fragile States: Productive Structure as the Missing Link

19. Carlota Perez, The New Technologies: An Integrated View

20. Carlota Perez, Technological revolutions and techno-economic paradigms

21. Rainer Kattel, Jan A. Kregel, Erik S. Reinert, The Relevance of Ragnar Nurkse and Classical Development Economics

22. Erik S. Reinert, Financial Crises, Persistent Poverty, and the Terrible Simplifiers in Economics: A Turning Point Towards a New "1848 Moment"

23. Rainer Kattel, Erik S. Reinert and Margit Suurna, Industrial Restructuring and Innovation Policy in Central and Eastern Europe since 1990

24. Erkki Karo and Rainer Kattel, The Copying Paradox: Why Converging Policies but Diverging Capacities for Development in Eastern European Innovation Systems?

25. Erik S. Reinert, Emulation versus Comparative Advantage: Competing and Complementary Principles in the History of Economic Policy

26. Erik S. Reinert, Capitalist Dynamics: A Technical Note

27. Martin Doornbos, Failing States or Failing Models?: Accounting for the Incidence of State Collapse 
28. Carlota Perez, The financial crisis and the future of innovation: $A$ view of technical change with the aid of history

29. Rainer Kattel and Annalisa Primi, The periphery paradox in innovation policy: Latin America and Eastern Europe Compared

30. Erkki Karo and Rainer Kattel, Is 'Open Innovation' Re-Inventing Innovation Policy for Catching-up Economies?

31. Rainer Kattel and Veiko Lember, Public procurement as an industrial policy tool - an option for developing countries?

32. Erik S. Reinert and Rainer Kattel, Modernizing Russia: Round III. Russia and the other BRIC countries: forging ahead, catching up or falling behind?

33. Erkki Karo and Rainer Kattel, Coordination of innovation policy in the catching-up context: Estonia and Brazil compared

34. Erik S. Reinert, Developmentalism

35. Fred Block and Matthew R. Keller, Where do Innovations Come From? Transformations in the U.S. Economy, 1970-2006

The working paper series is edited by Rainer Kattel (kattel@staff.ttu.ee),

Wolfgang Drechsler (drechsler@staff.ttu.ee), and Erik S. Reinert (reinert@staff.ttu.ee), who all of them will be happy to receive submissions, suggestions or referrals. 